\title{
VARIASI DAN HUBUNGAN FENETIK AKSESI KUNYIT DI YOGYAKARTA DAN SEKITARNYA
}

\section{(VARIATION AND PHENETIC RELATIONSHIP OF TUMERIC ACCESSIONS IN YOGYAKARTA AND SURROUNDING AREAS)}

\author{
Aditiana Vimala Guna dan Purnomo \\ Fakultas Biologi, Universitas Gadjah Mada Indonesia \\ Jl. Teknika Selatan, Senolowo, Sinduadi, Mlati, Sleman Yogyakarta 55281 \\ email: aditiana.vimala.guna@mail.ugm.ac.id
}

\begin{abstract}
Abstrak
Tujuan penelitian ini adalah menentukan variasi morfologis dan anatomis tiap aksesi Curcuma longa, serta hubungan fenetik pada spesies antar aksesi Curcuma longa. Sebanyak 13 sampel diambil di area Yogyakarta dan sekitarnya, karakter morfologis yang dibandingkan bersumber dari akar, rimpang, daun meliputi bentuk dan ukuran. Karakter anatomis diamati pada daun dan rimpang. Penentuan karakter morfologis berdasarkan Protection of Plant Varieties dan Farmers' Rights Authority. Hubungan fenetik menggunakan perbandingan karakter morfologis dan anatomis spesies Curcuma longa yang diteliti. Hasil penelitian menunjukkan variasi morfologis Curcuma longa di Yogyakarta dan sekitarnya memiliki perbedaan tinggi tanaman, morfologis daun, serta morfologis akar dan rimpang. Variasi karakter anatomis Curcuma longa memiliki perbedaan ketebalan epidermis daun, ukuran dan densitas stomata, ketebalan berkas pengangkut, ketebalan epidermis dan hipodermis rimpang. Berdasarkan analisis fenetik Curcuma longa di Yogyakarta dan sekitarnya dapat diketahui bahwa hubungan kekerabatan fenetik berdasarkan karakter morfologis terbagi menjadi dua klaster besar dan empat subklaster, sedangkan berdasarkan karakter anatomis terbagi menjadi dua klaster dan enam subklaster.
\end{abstract}

Kata kunci: Curcuma longa, morfologi dan fenetik

\begin{abstract}
The purpose of this study was to determine the morphological and anatomical variations of each accession of Curcuma longa, as well as the phenetic relationship among accessions of Curcuma longa. A total of 13 samples were taken in the Yogyakarta and surrounding areas, the morphological characters compared from roots, rhizomes, leaves include shape and size. The anatomical characters were observed in the leaves and rhizomes. The determination of morphological characters based on Protection of Plant Varieties and Farmers' Rights Authority. The phenetic relationship used a comparison of the morphological and anatomical characters of the Curcuma longa species studied. The results showed that the morphological variations of Curcuma longa in Yogyakarta and its surroundings had differences in plant height, leaf morphology, and root and rhizome morphology. Variations in anatomical characters of Curcuma longa have differences in leaf epidermis thickness, stomata size and density, carrier bundle thickness, epidermis and rhizome hypodermis thickness. Based on the phenetic analysis of Curcuma longa in Yogyakarta and its surroundings, it shows phenetic relationship based on morphological characters is divided into two large clusters and four sub-clusters, while based on anatomical characters it is divided into two clusters and six sub-clusters.
\end{abstract}

Keywords: Curcuma longa, morphology and phenetic 


\section{PENDAHULUAN}

Indonesia merupakan negara yang dilintasi garis khatulistiwa sehingga beriklim tropis. Hal tersebut mendukung adaptasi flora dan fauna yang beranekaragam. Keanekaragaman tersebut menciptakan berbagai bahan baku untuk digunakan dalam kehidupan sehari-hari (Iskandar, 2016). Curcuma longa L. atau kunyit merupakan anggota familia Zingiberaceae yang banyak ditemukan di Indonesia. C. longa memiliki karakteristik berupa tumbuhan menahun, batang bermodifikasi menjadi rimpang, daun menyirip berligula, bunga biseksual, zigomorf, daun pelindung tipis, kelopak menabung, mahkota memanjang dengan warna merah muda hingga ungu, serta buah dan biji berbentuk elips (Trimanto dkk., 2017). Hasil penelitian dari Trimanto dkk. (2017) juga menyebutkan struktur anatomis rimpang menyerupai batang yang mana terdiri dari epidermis, hipodermis, parenkim, dan berkas pengangkut. Penelitian mengenai struktur organ C. longa masih sedikit diteliti, terutama pada struktur anatomis.

Keanekaragaman variasi spesies $C$. longa tentunya merupakan potensi penelitian yang dapat dikembangkan. Proses evolusi yang menyebabkan keanekaragaman tersebut tentunya merupakan salah satu kajian yang penting, terutama dalam ilmu Sistematika Tumbuhan. Hubungan kekerabatan aksesi dari setiap spesies $C$. longa mampu menunjukkan proses evolusi yang terjadi karena berbagai macam faktor. Informasi hubungan kekerabatan pada tingkat dibawah spesies $C$. longa dapat menjadi sumbangan dalam klasifikasi tumbuhan $C$. longa. Hubungan kekerabatan berdasarkan karakter fenotip juga dapat menjadi dasar penelitian untuk memperoleh suatu bibit unggul dari kedekatan suatu spesies dengan spesies lainnya (Fajar dkk., 2016).

Tujuan dilakukannya penelitian ini untuk mengetahui variasi morfologis dan anatomis, serta hubungan kekerabatan fenetik pada aksesi kunyit di Yogyakarta dan sekitarnya.

\section{METODE}

Bahan yang digunakan pada penelitian adalah berbagai sampel aksesi dari spesies Curcuma longa L. yang diperoleh dari Yogyakarta dan sekitarnya, serta bahan kimia untuk pembuatan preparat antara lain safranin $1 \%$, alkohol $70 \%$, kertas label, tisu, gelas benda, gelas penutup, botol flakon, dan akuades. Alat yang digunakan untuk koleksi sampel dan dokumentasi antara lain Zipplock berbagai ukuran, etiket gantung atau kertas label, sekop kecil, dan kamera. Alat yang digunakan pada pembuatan dan pengamatan preparat antara lain cutter, pinset, pipet tetes, kuas, gelas beker, cawan petri, scalpel, Sliding microtome, mikroskop, dan optilab. Alat yang digunakan untuk pengukuran parameter lingkungan antara 
lain termometer, soil tester, higrometer, altimeter, dan luxmeter.

Pengambilan sampel dilakukan di wilayah Yogyakarta dan sekitarnya, serta mengukur parameter lingkungan di setiap titik pengambilan sampel. Penentuan karakter morfologis berdasarkan Protection of Plant Varieties and Farmers' Rights Authority (PPV dan FRA) Tahun 2007, dilakukan dengan pengamatan langsung dan dilakukan pengambilan foto dengan kamera pada karakter spesifik. Karakter kuantitatif diukur dengan mistar. Pembuatan preparat anatomis dilakukan dengan metode free hand sectioning dengan bentuk preparat akhir semi permanen. Rimpang dibersihkan kemudian dipotong menggunakan sliding microtome dengan ketebalan $\pm 20 \mu \mathrm{m}$. Irisan diambil dengan menggunakan kuas dan dimasukkan ke dalam botol flakon berisi alkohol $70 \%$. Sebelum pengamatan menggunakan mikroskop dan optilab, irisan diwarnai dengan menggunakan safranin $1 \%$ dalam alkohol $70 \%$ selama 5-10 menit. Selanjutnya dibilas dengan alkohol sebanyak 3 kali. Irisan kemudian diletakkan di atas kaca benda dan ditutup dengan kaca penutup.

Daun yang digunakan untuk pengamatan merupakan daun pertama atau kedua, ketiga, dan keempat pada tanaman sebagai ulangan. Bagian yang diamati merupakan midrib daun. Proses pembuatan preparat daun dilakukan seperti pada pembuatan preparat rimpang. Ketentuan karakter anatomis berdasarkan penelitian Roy et al. (2013), serta penambahan berdasarkan karakter yang teramati.

Pengamatan sel yang mengandung minyak eteris dilakukan dengan melakukan pengirisan rimpang utama segar menggunakan sliding microtome, kemudian diletakkan pada kaca benda yang ditetesi akuades dan ditutup menggunakan kaca penutup. Selanjutnya, densitas sel minyak diamati menggunakan mikroskop dengan perbesaran $4 \times 10$. Pada pengamatan bagian paradermal daun diamati jenis dan densitas stomata. Daun yang diamati merupakan daun pertama atau kedua, ketiga, dan keempat pada tanaman sebagai ulangan. Daun disayat tipis menggunakan cutter, kemudian sayatan diambil menggunakan kuas dan diletakkan pada cawan petri yang berisi campuran alkohol $70 \%$ dan safranin $1 \%$. Setelah 5 menit sayatan diletakkan pada kaca benda kemudian diberi larutan dan ditutup dengan kaca penutup. Pengamatan menggunakan mikroskop cahaya dengan perbesaran $10 \times 10$ dan 40x10 kemudian diambil foto dengan optilab.

\section{HASIL DAN PEMBAHASAN}

Koleksi sampel yang berjumlah 13 aksesi merupakan tanaman budidaya dan tanaman liar. Dari 13 sampel yang diperoleh, sampel aksesi 1, 3, 5, 10, 11, 12, dan 13 
merupakan tanaman budidaya. Tiap aksesi memiliki kisaran altitude antara $112 \mathrm{mdpl}$ hingga 955 mdpl. Titik pengambilan sampel yang kurang merata dikarenakan karakter morfologis dari kunyit memiliki kemiripan dengan karakter temu mangga (Curcuma amada Roxb.). Hal ini menjadi salah satu hambatan dalam koleksi sampel, dikarenakan untuk mengetahui perbedaan spesies $C$. longa dengan tanaman lainnya diperlukan pemeriksaan lebih lanjut pada bagian rimpang. Rimpang kunyit memiliki warna oranye, sedangkan rimpang temu mangga memiliki warna kekuningan (Naik, 2012).

Karakter morfologis yang diamati yaitu daun, rimpang, dan akar. Organ bunga tidak dapat dijadikan karakter pengamatan dikarenakan hanya terdapat satu tanaman yang memiliki organ bunga. Fase perbungaan kunyit berlangsung antara 109-155 hari setelah ditanam, dengan waktu pemekaran sekitar 7-11 hari (Ravindran et al., 2007). Ravindran et. al. (2007) juga menyebutkan periode perbugaan $C$. longa berlangung antara bulan September hingga Desember. Berikut merupakan variasi morfologis yang telah diamati.

Pertama, variasi morfologis. Perawakan yang digunakan sebagai karakter adalah tinggi tanaman. Menurut Dinas Pertanian Provinsi Yogyakarta dan Pusat Penyuluhan Pertanian Kementrian Pertanian tanaman kunyit memiliki tinggi habitus $40-100 \mathrm{~cm}$. Berdasarkan ketentuan PPV dan FRA (2007), tinggi tanaman kunyit dibedakan menjadi pendek $(<85 \mathrm{~cm})$, sedang $(85-100 \mathrm{~cm})$, dan

Tabel 1

Parameter Lingkungan Terukur pada masing-masing Lokasi Pengambilan Sampel

\begin{tabular}{|c|c|c|}
\hline $\begin{array}{l}\text { Nomor } \\
\text { Aksesi }\end{array}$ & Parameter lingkungan & Lokasi \\
\hline Aksesi 1 & Alt: 699 , s.u.: 29 , l.u. 49 : , i.c.: $237 x 100$, s.t.: 33 , l.t.: 80 , pH: 6.8 & Pakem, Sleman \\
\hline Aksesi 2 & Alt: 621 , s.u.: 30 , l.u.: 49 , i.c.: $621 \times 100$, s.t.: 27 , l.t.: 55 , pH: 6.4 & Girimulyo, Kulon Progo \\
\hline Aksesi 3 & Alt: 112 , s.u.: 34 , l.u.: 55 , i.c.: $286 x 100$, s.t.: 32 , l.t.: 75 , pH: 7 & Banguntapan, Bantul \\
\hline Aksesi 4 & Alt: 133 , s.u.: 33 , l.u.: 40 , i.c.: $36 x 100$, s.t.: 28.5 , l.t.: 55 , pH: 6.8 & Nanggulan, Kulon Progo \\
\hline Aksesi 5 & Alt: 334 , s.u.: 28 , 1.u.: 45 , i.c.: $254 x 100$, s.t.: 29 , 1.t.: 45 , pH: 6.8 & Dlingo, Bantul \\
\hline Aksesi 6 & Alt: 159 , s.u.: 32 , l.u.: 67 , i.c.: $561 \times 100$, s.t.: 28 , 1.t.: 40 , pH: 6.6 & Depok, Sleman \\
\hline Aksesi 7 & Alt: 168 , s.u.: 33 , 1.u.: 46 , i.c.: $51.4 x 100$, s.t.: 29 , 1.t.: 55 , pH: 6.5 & Depok, Sleman \\
\hline Aksesi 8 & Alt: 202 , s.u.: 33 , l.u.: 51 , i.c.: $136.6 \times 100$, s.t.: 28 , 1.t.: 85 , pH: 6.8 & Wonosari, Gunung Kidul \\
\hline Aksesi 9 & Alt: 427 , s.u.: 30 , 1.u.: 62 , i.c.: $82.5 \times 100$, s.t.: 28 , 1.t.: 40 , pH: 6.8 & Pakem, Sleman \\
\hline Aksesi 10 & Alt: 140 , s.u.: 30 , l.u.: 62 , i.c.: $478 \times 100$, s.t.: 29 , 1.t.: 50 , pH: 6.8 & Depok, Sleman \\
\hline Aksesi 11 & Alt: 141 , s.u.: 31 , l.u.: 55 , i.c.: $333 \times 100$, s.t.: 28 , 1.t.: 68 , pH: 6.8 & Depok, Sleman \\
\hline Aksesi 12 & Alt: 955 , s.u.: 27 , l.u.: 72 , i.c.: $175 x 100$, s.t.: 28 , l.t.: 100 , pH: 6.6 & Pringsurat, Temanggung \\
\hline Aksesi 13 & Alt: 130 , s.u.: 29 , 1.u.: 65 , i.c.: $50.64 x 100$, s.t.: 31 , 1.t.: 75 , pH: 6.6 & Gamping, Sleman \\
\hline
\end{tabular}

Keterangan: Alt: altitude (mdpl), s.u.: suhu udara, 1.u.: kelembapan udara, i.c.: intensitas cahaya, s.t.: suhu tanah, 1.t.: kelembapan tanah. 
tinggi $(>100 \mathrm{~cm})$. Namun, dikarenakan tinggi tanaman yang terukur pada kisaran 85-130 $\mathrm{cm}$ sehingga hasil yang digunakan untuk perbandingan adalah sedang $(<100 \mathrm{~cm})$ dan tinggi $(>100 \mathrm{~cm})$. Gambar 1a merupakan akasesi 7 yang memiliki ketinggian mencapai $130 \mathrm{~cm}$, sedangkan Gambar 1b merupakan aksesi 12 yang memiliki ketinggian $85,5 \mathrm{~cm}$.

Aksesi 7 merupakan tanaman liar dengan tidak adanya perawatan, sedangkan aksesi 12 merupakan tanaman budidaya yang diberi perawatan. Kondisi lingkungan aksesi 7 memiliki intensitas cahaya terukur sebesar 51,4 x 100 lux dengan naungan kanopi di sekitarnya. Berbeda dengan aksesi 7, pada aksesi 12 memiliki intensitas cahaya terukur sebesar $175 \times 100$ lux tanpa naungan kanopi di sekitarnya. Hal ini kemungkinan dapat menjadi pengaruh perbedaan tinggi tanaman. Pergerakan tumbuhan yang mendekati arah cahaya (fototropisme) merupakan respon adaptif dari tumbuhan untuk memperoleh energi fotosintesis (Campbell et al., 2012). Pertumbuhan tanaman juga dipengaruhi oleh aktivitas hormon seperti auksin (IAA), sitokinin, giberelin, asam absisat (ABA), dan etilen. Salah satu hormon yang merangsang pemanjangan sel adalah auksin. Hormon auksin dapat merangsang pemanjangan sel dengan konsentrasi 0,9 g/l. Produksi auksin yang banyak akan

Gambar 1

Perawakan Tanaman Curcuma longa Aksesi 7(a) dan 12(b)
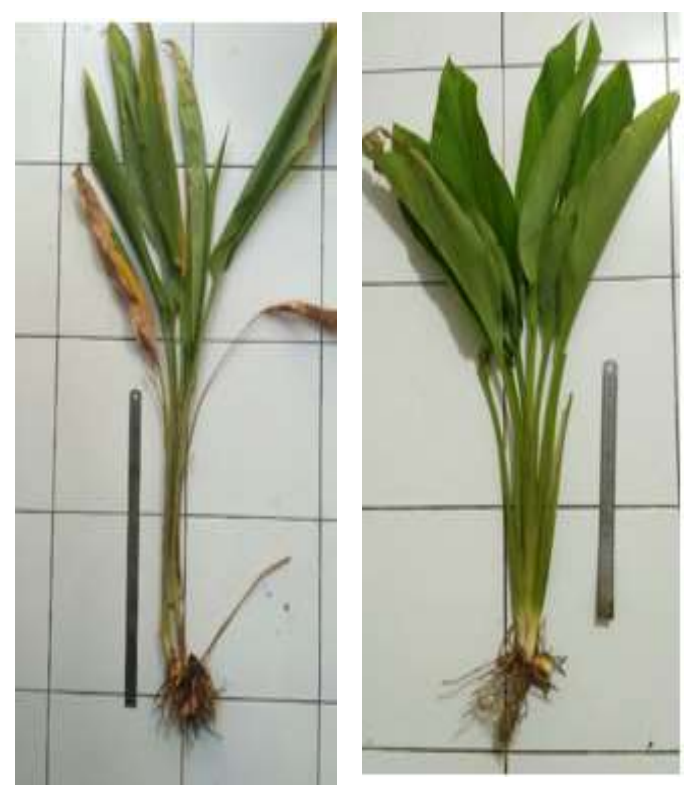

Keterangan: $\mathrm{H}$; helaian daun, T; tangkai daun, $\mathrm{P}$; pelepah daun, A; akar, R; rimpang. 
memicu tanaman mensintesis hormon etilen yang dapat meng-hambat pertumbuhan (Pujiasmanto, 2020).

Organ daun seluruh aksesi Curcuma longa memiliki bentuk bulat memanjang (oblongus) (Gambar 2). Hal tersebut dikarenakan dalam penentuan bentuk daun digunakan perbandingan panjang : lebar dari helaian daun. Bentuk bulat memanjang memiliki perbandingan panjang : lebar helaian yaitu 2,5-5: 1 (Nugroho dkk., 2012). Berdasarkan sampel tiap akasesi yang diperoleh, perbandingan panjang : lebar daun pada sampel termasuk dalam kategori tersebut.

Lebar helaian daun tiap aksesi menjadi salah satu karakter pembeda. Aksesi 3 (Gambar 2a) yang merupakan tanaman budidaya memiliki karakter daun dengan lebar daun lebih besar dibandingkan pada aksesi 6 (Gambar 2b) yang merupakan tumbuhan liar. Lebar daun tersebut berpengaruh terhadap nilai luas permukaan daun. Luas permukaan daun dapat dipengaruhi oleh kondisi lingkungan dan ketersediaan hara.

Intensitas cahya terukur di titik sampling aksesi 3 adalah 286x100 lux, sedangkan pada titik sampling aksesi 6 adalah 561x100. Intensitas cahaya tinggi dapat menurunkan kadar klorofil sehingga akan menunjukkan perubahan daun menjadi kekuningan (Anni dkk., 2013). Perubahan tersebut ditunjukkan pada daun aksesi 6 (Gambar 2b) yang mengalami perubahan warna menjadi kekuningan. Daun yang memiliki luas

Gambar 2

Daun Curcuma longa Aksesi 3(a) dan Aksesi 6(b)
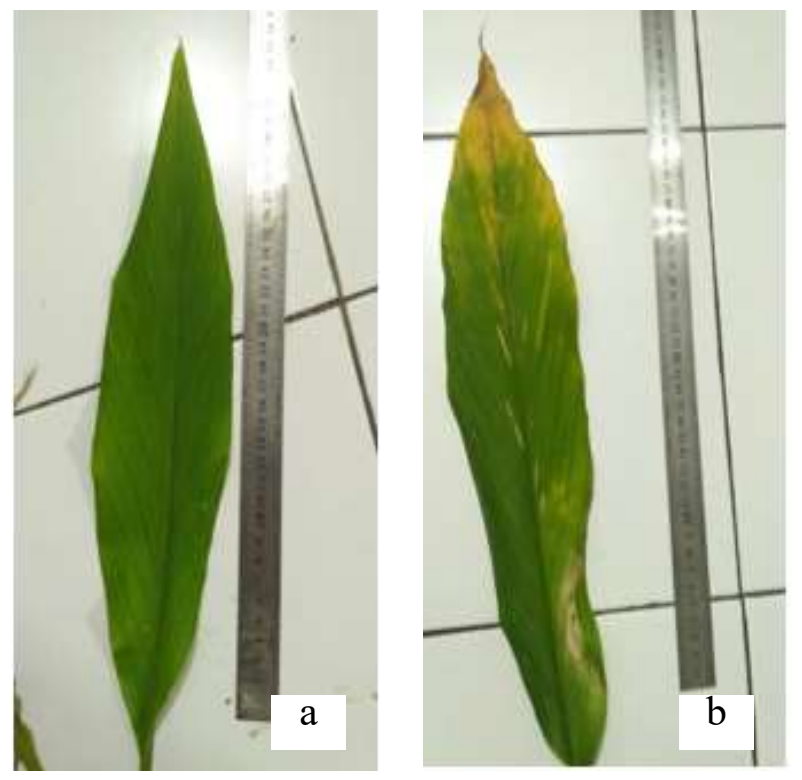
permukaan lebih kecil beradaptasi untuk mengurangi proses penguapan sehingga ketersediaan air pada tumbuhan tercukupi. Ketersediaan air dan hara pada aksesi 3 dapat dikatakan tercukupi karena dilakukan perawatan sehingga dapat mengimbangi laju repirasi.

Karakter lain yang teramati adalah pola venasi pada helaian daun. Lebar antara dua vena paralel yang berdekatan diamati secara visual untuk dikategorikan arakternya. Hasil yang diamati menunjukkan terdapat pola venasi rapat dan berjarak yang ditampilkan pada Gambar 3. Aksesi yang memiliki pola venasi rapat terdapat pada aksesi 3,7 , dan 10.

Selanjutnya terdapat karakter pola batang semu yang merupakan bentuk perlekatan dari pelepah daun. Variasi perlekatan pelepah daun dibedakan menjadi kompak dan terbuka Gambar 4). Hasil yang diperoleh menunjukkan pada aksesi 11, 12, dan 13 memiliki pola batang semu yang terbuka.

Bentuk helaian daun Curcuma longa juga memiliki dua macam bentuk tepi yaitu bergelombang dan rata. Hasil yang diperoleh menunjukkan pada aksesi 1, 5, 6, 11, 12, dan 13 memiliki bentuk tepi bergelombang. Perbedaan bentuk tepi dapat dilihat pada Gambar 5.

Curcuma longa L. memiliki organ batang yang mengalami metamorfosis menjadi rimpang. Bagian rimpang ini banyak dimanfaatkan oleh masyarakat secara tradisional ataupun moderen, terutama pada bagian rimpang samping.

Kunyit dimanfaatkan oleh masyarakat sebagai bumbu masak, obat tradisional ataupun moderen, antioksidan, antibakteri, antiinflamatori, dan antiprotozoa (Silalahi, 2017). Karakter morfologis pada rimpang

\section{Gambar 3}

Perbedaan Pola Venasi pada Aksesi 2 yang Berjarak (a) dan Aksesi 7 yang Rapat (b)

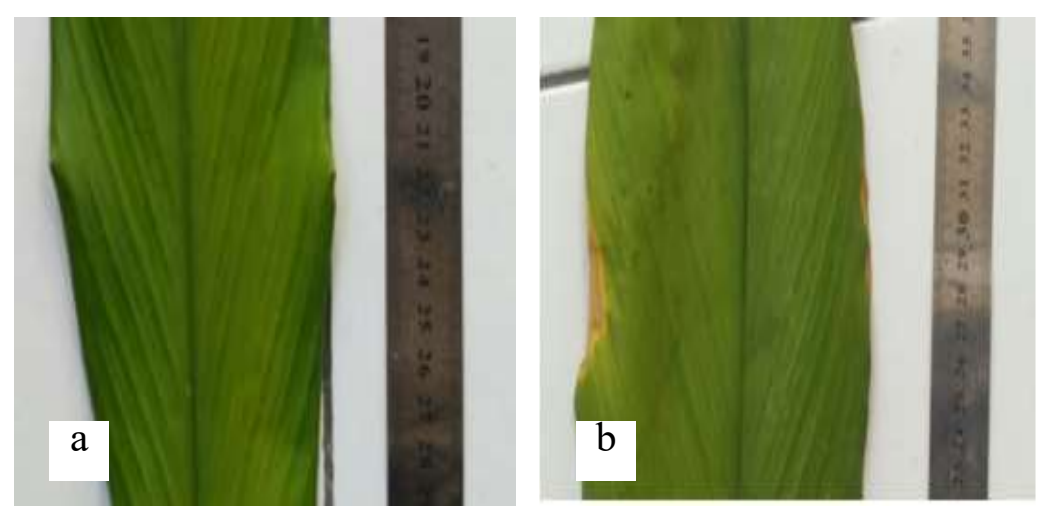


Gambar 4

Perbedaan antara Batang Semu yang Terbuka pada Aksesi 12(a) dan Batang Semu yang Kompak pada Aksesi 1(b)
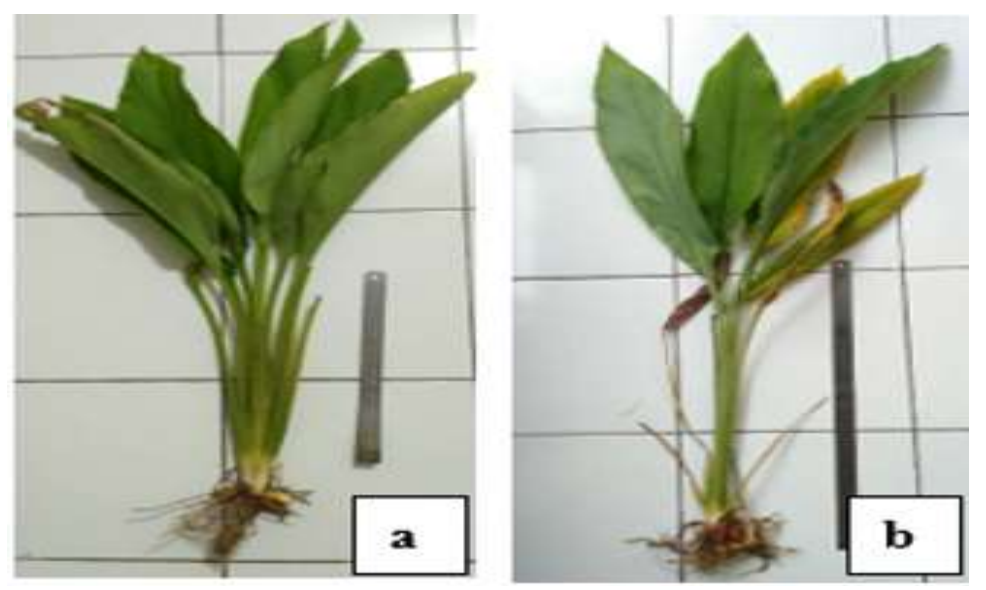

Gambar 5

Bentuk Tepi Daun yang Bergelombang pada Aksesi 6(a) dan Bentuk Tepi Daun Rata pada Aksesi 9(b)

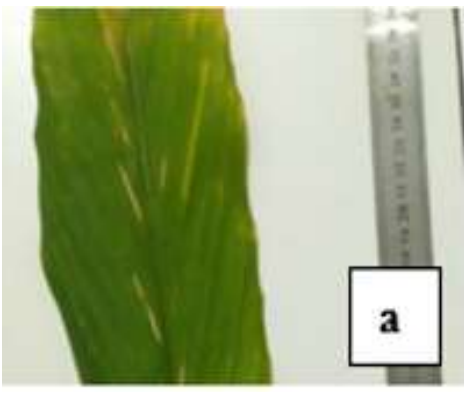

15 karakter termasuk

menghasilkan perakaran.

Aksesi 5 memiliki kerimbunan rimpang samping yang banyak, tetapi memiliki kerimbunan akar yang sedikit (Gambar 6a). Kondisi akar pada aksesi 6 memiliki kerimbunan yang banyak, tetapi memiliki kerimbunan rimpang samping yang sedikit

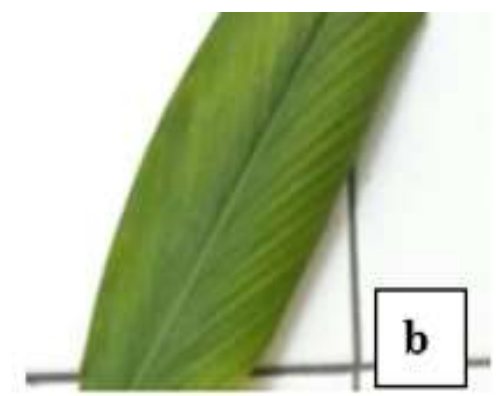

(Gambar 6b). Berbeda dengan keduanya, pada aksesi 11 memiliki kerimbunan akar dan kerimbunan rimpang yang sedikit (Gambar 6c). Berdasarkan habitat ketiga aksesi tersebut, aksesi 5 dan 11 merupakan tanaman budidaya, sedangkan aksesi 6 merupakan tumbuhan liar. Kebutuhan hara pada tanaman buddaya dapat diakatan tercukupi sehingga 
Gambar 6

Kerimbunan Akar dan Rimpang Curcuma longa pada Aksesi 5(a), Aksesi 6(b), dan Aksesi 11(c) (Dokumen pribadi)
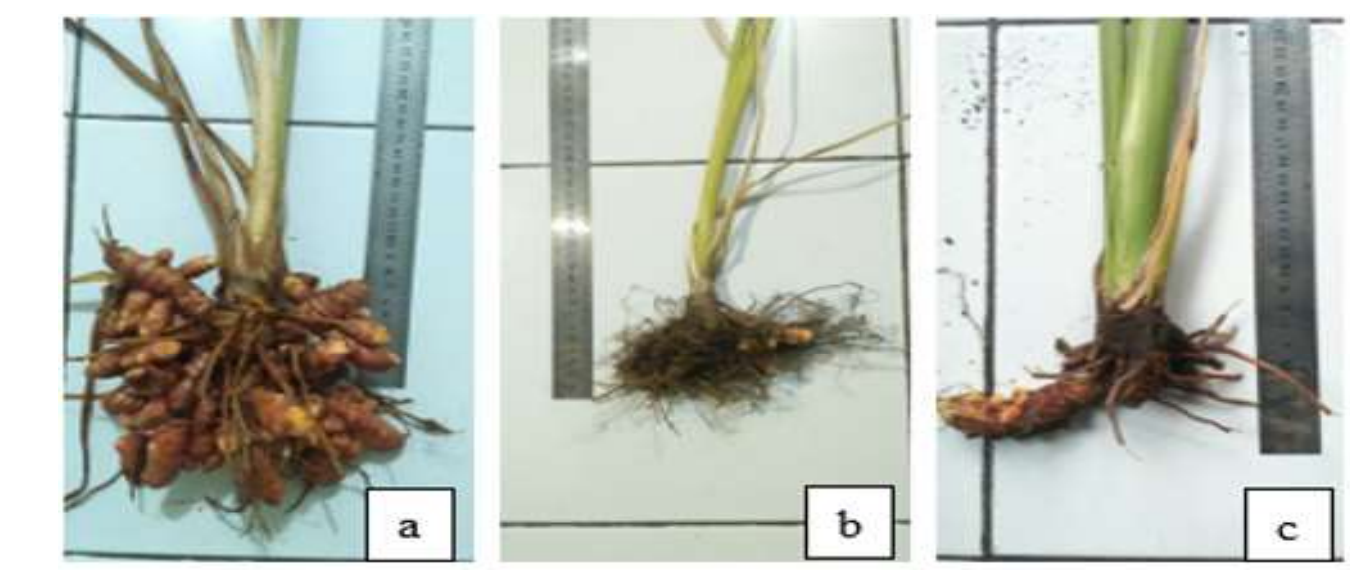

mampu menghasilkan rimpang samping yang rimbun. Rimpang memiliki peranan fisiologis salah satunya sebagai tempat menyimpan cadangan makanan (Nugroho dkk., 2012). Aksesi 5 yang merupakan tanaman budidaya memperoleh unsur hara yang cukup sehingga pembentukan cadangan makanan lebih banyak. Berbeda dengan aksesi 5, pada aksesi 6 memiliki kerimbunan rimpang samping yang sedikit. Kurangnya nutrien tanah dapat menjadi sebab kerimbunan akar yang banyak pada aksesi 6 . Kondisi cekaman kekeringan dapat mempengaruhi sistem perakaran pada jumlah atau volume akar (Lynch \& Brown, 2012). Perakaran pada aksesi 6 mengalami penambahan akar dan mengalami pengurangan volume akar. Aksesi 11 memiliki kerimbunan rimpang samping dan kerimbunan akar yang sedikit. Hal ini kemungkinan dikarenakan usia tanaman yang belum dewasa sehingga petumbuhan masih terbatas.

Bentuk rimpang juga menjadi karakter yang berperan aelain kerimbunan akar dan rimpang. Rimpang aksesi 1 memiliki bentuk lebih elips (Gambar 7a), sedangkan pada rimpang aksesi lainnya memiliki bentuk silindris. Pengaruh bentuk rimpang ini dapat dikarenakan media tanam yang sempit sehingga betuk rimpang menyesuaikan kondisi lahan.

Selain bentuk diagonal rimpang utama, bentuk rimpang samping memiliki variasi berbentuk lurus dan melengkung (Gambar 8). Aksesi yang memiliki bentuk rimpang samping melengkung terdapat pada aksesi 3 , $5,6,7,11$, dan 12. Perbedaan bentuk rimpang tersebut ditampilkan pada Gambar 9.

Warna kulit rimpang samping juga menjadi karakter pembeda pada beberapa 
Gambar 7

Potongan Melintang Rimpang Utama Curcuma longa Aksesi 1(a) dan Aksesi 9(b)
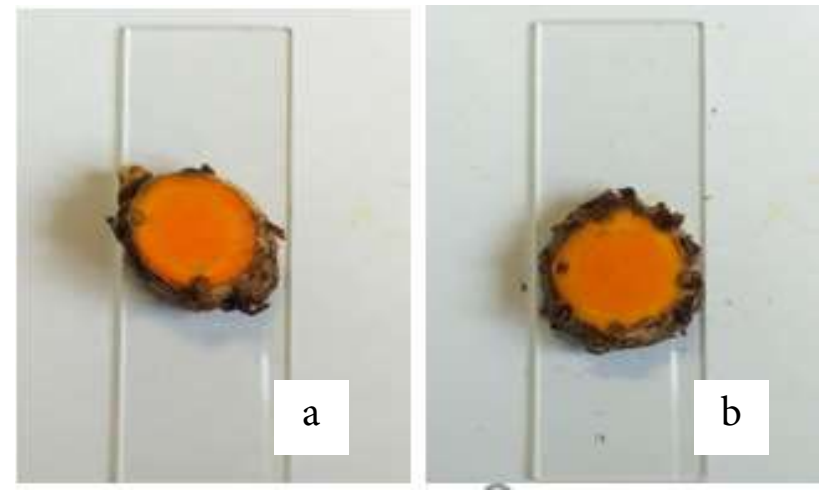

Gambar 8

Bentuk Rimpang Samping yang Melengkung pada Aksesi 3(a) dan Bentuk Rimpang Samping yang Lurus pada Aksesi 13(b)
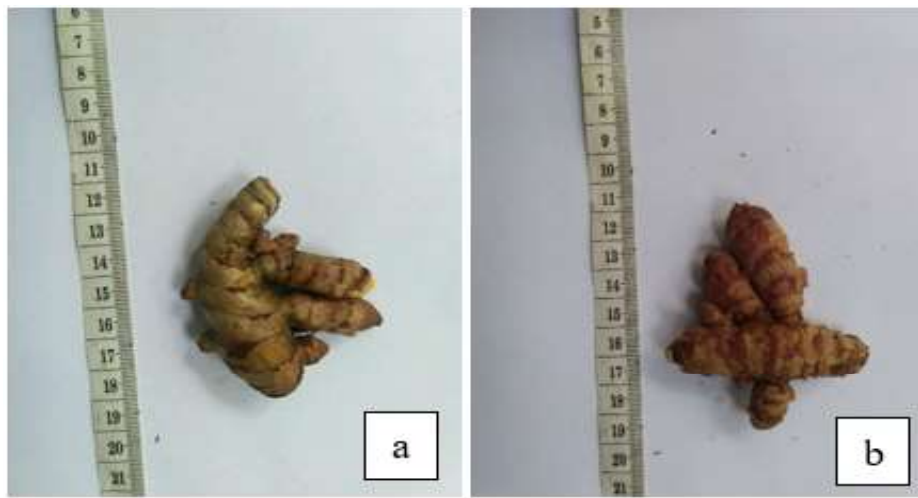

aksesi. Kulit rimpang samping menunjukkan warna oranye dan warna kecoklatan (Gambar 9). Kulit rimpang samping aksesi 3 memiliki warna kecoklatan (Gambar 9a), sedangkan pada aksesi 12 menunjukkan warna oranye (Gambar 9b). Warna yang terbentuk dapat disebabkan oleh ketebalan dari kuit rimpang samping. Daging rimpang samping secara keseluruhan memiliki warna oranye, sehingga kulit rimpang samping yang lebih tipis akan menunjukkan gradasi warna lebih oranye.

Karakter morfologis yang telah diperoleh kemudian digunakan untuk tabulasi data berbentuk biner, dan dilakukan pemberian skor. Terdapat 25 karakter morofologis yang 
Gambar 9

Rimpang Samping Curcuma longa Aksesi 3(a) dan Aksesi 12(b)
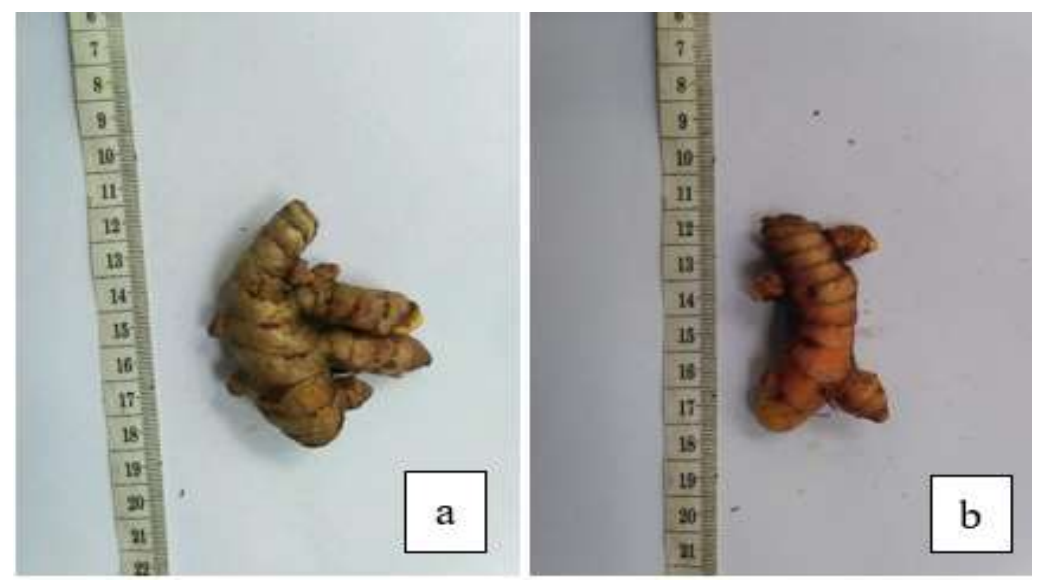

telah diubah menjadi data biner dengan skor yang ditampilkan pada Tabel 2 .

Penentuan karakter untuk rekonstruksi dendrogram pada tingkat takson infraspesies memiliki jumlah yang lebih sedikit dibandingkan pada taksa spesies. Karakter untuk tingkat infraspesies yang kurang dari 50 masih dapat digunakan dalam analisis fenetik (Salimpour et al., 2012).

Hasil skor karakter kemudian diolah menggunakan program Multivariate Stastitical Package (MVSP) untuk menampilkan dendrogram. Hubungan kekerabatan yang dianalisis dengan MVSP memiliki dasar persamaan atau perbedaan karakter yang dimiliki. Dalam konstruksi dendrogram digunakan metode pengklasteran dengan algoritma average linkage atau Unweighted Pair Group Method (UPGMA). Pengukuran similaritas pada konstruksi dendrogam digunakan indeks similaritas SSM (SimpleMatching Coefficient). Metode pengklasteran digunakan untuk pengelompokan aksesi berdasarkan indeks similaritas. Nilai yang tertera pada garis cabang menunjukkan hubungan kekerabatan dari aksesi yang berpasangan. Garis cabang tersebut akan membentuk suatu klaster yang kemudian membentuk dendrogram (Dharmayanti, 2011).

Dendrogram diberi garis fenon pada nilai indeks similaritas 0,6. Beberapa argumen menyatakan bahwa garis fenon pada tingkat spesies berada pada ambang $80 \%, 65 \%$, dan $45 \%$ (Singh, 2004). Namun, penentuan garis fenon merupakan sewenangwenang dan pengelompokan relatif (Naik, Taxonomy of Angiosperms, 2006). Garis dendrogram yang mendekati angka satu menunjukkan persamaan karakter yang lebih 
Tabel 2

Presensi dan Absensi setiap Karakter Morfologis san Anatomis yang Dibandingkan

\begin{tabular}{|c|c|c|c|c|c|c|c|c|c|c|c|c|c|c|}
\hline \multirow{2}{*}{ No } & \multirow{2}{*}{ Karakter } & \multicolumn{13}{|c|}{ OTU } \\
\hline & & 1 & 2 & 3 & 4 & 5 & 6 & 7 & 8 & 9 & 10 & 11 & 12 & 13 \\
\hline 1 & Tinggi maksimal & 0 & 1 & 1 & 1 & 1 & 1 & 1 & 0 & 1 & 1 & 1 & 0 & 1 \\
\hline 2 & Keimbunan akar & 0 & 1 & 1 & 1 & 1 & 0 & 0 & 0 & 1 & 0 & 1 & 1 & 0 \\
\hline 3 & Diameter akar & 0 & 1 & 1 & 1 & 1 & 0 & 1 & 1 & 0 & 0 & 0 & 0 & 0 \\
\hline 4 & Kerimbunan rimpang samping & 0 & 0 & 1 & 1 & 1 & 0 & 0 & 0 & 0 & 0 & 0 & 0 & 0 \\
\hline 5 & Bentuk diagonal rimpang utama & 1 & 0 & 0 & 0 & 0 & 0 & 0 & 0 & 0 & 0 & 0 & 0 & 0 \\
\hline 6 & Bentuk rimpang samping & 0 & 0 & 1 & 0 & 1 & 1 & 1 & 0 & 0 & 0 & 1 & 1 & 0 \\
\hline 7 & Panjang rimpangutama & 0 & 1 & 0 & 1 & 1 & 0 & 1 & 0 & 1 & 1 & 1 & 0 & 0 \\
\hline 8 & Panjang rimpang samping & 0 & 1 & 1 & 1 & 0 & 1 & 0 & 0 & 1 & 0 & 0 & 1 & 0 \\
\hline 9 & Panjang cabang rimpang samping & 0 & 1 & 1 & 0 & 1 & 0 & 0 & 1 & 1 & 0 & 1 & 1 & 0 \\
\hline 10 & Jarak antar nodus rimpang utama & 0 & 1 & 0 & 0 & 1 & 1 & 1 & 0 & 0 & 0 & 1 & 1 & 0 \\
\hline 11 & Jarak antar nodus rimpang samping & 0 & 1 & 1 & 1 & 0 & 0 & 0 & 0 & 1 & 1 & 1 & 0 & 0 \\
\hline 12 & $\begin{array}{l}\text { Jarak antar nodus cabang rimpang } \\
\text { samping }\end{array}$ & 0 & 0 & 0 & 1 & 1 & 0 & 0 & 0 & 1 & 1 & 1 & 1 & 0 \\
\hline 13 & Diameter rimpang utama & 0 & 1 & 1 & 1 & 1 & 0 & 0 & 0 & 0 & 1 & 1 & 1 & 0 \\
\hline 14 & Diameter rimpang samping & 0 & 0 & 0 & 0 & 1 & 0 & 0 & 0 & 1 & 1 & 1 & 1 & 0 \\
\hline 15 & Diameter cabang rimpang samping & 0 & 1 & 1 & 0 & 1 & 0 & 0 & 1 & 0 & 0 & 0 & 1 & 0 \\
\hline 16 & Warna kulit rimpang samping & 0 & 0 & 0 & 0 & 0 & 0 & 0 & 0 & 1 & 0 & 0 & 1 & 0 \\
\hline 17 & Jumlah Daun & 0 & 0 & 0 & 0 & 0 & 0 & 1 & 1 & 0 & 0 & 1 & 1 & 1 \\
\hline 18 & Pola batang semu & 0 & 0 & 0 & 0 & 0 & 0 & 0 & 0 & 0 & 0 & 1 & 1 & 1 \\
\hline 19 & Panjang pelepah daun & 0 & 0 & 0 & 1 & 1 & 1 & 1 & 0 & 0 & 1 & 0 & 0 & 1 \\
\hline 20 & $\begin{array}{l}\text { Bentuk perlekatan pelepah dengan } \\
\text { rimpang }\end{array}$ & 0 & 1 & 1 & 1 & 1 & 1 & 1 & 1 & 1 & 1 & 1 & 1 & 1 \\
\hline 21 & Panjang tangkai daun & 0 & 1 & 0 & 1 & 0 & 0 & 1 & 0 & 0 & 1 & 0 & 0 & 0 \\
\hline 22 & Lebar helaian daun & 1 & 1 & 0 & 1 & 1 & 0 & 1 & 1 & 1 & 1 & 1 & 1 & 1 \\
\hline 23 & Panjang helaian daun & 0 & 0 & 0 & 1 & 1 & 0 & 1 & 0 & 0 & 1 & 0 & 0 & 1 \\
\hline 24 & Bentuk tepi helaian daun & 1 & 0 & 0 & 0 & 1 & 1 & 0 & 0 & 0 & 0 & 1 & 1 & 1 \\
\hline 25 & Pola venasi & 1 & 1 & 0 & 1 & 1 & 1 & 0 & 1 & 1 & 0 & 1 & 1 & 1 \\
\hline
\end{tabular}

banyak sehingga dapat dikatakan hubungan kekerabatan Operational Taxonomy Unit (OTU) semakin dekat. Hasil analisis karakter menunjukkan 13 aksesi $C$. longa membentuk dua klaster dengan masing-masing klaster memiliki dua subklaster (Gambar 10). Subklaster I.1 terdiri dari aksesi 5, 11, dan
12, serta subklaster I.2 terdiri dari aksesi 9, 3, dan 2. Subklaster II.1 terdiri dari aksesi 7, 10, dan 4, serta subklaster II.2 terdiri dari aksesi 13, 6, 8, dan 1 .

Melalui dendrogram pada gambar 10 dapat dikeahui pasangan aksesi 11 dan 12 serta aksesi 10 dan 4, kedua pasangan 


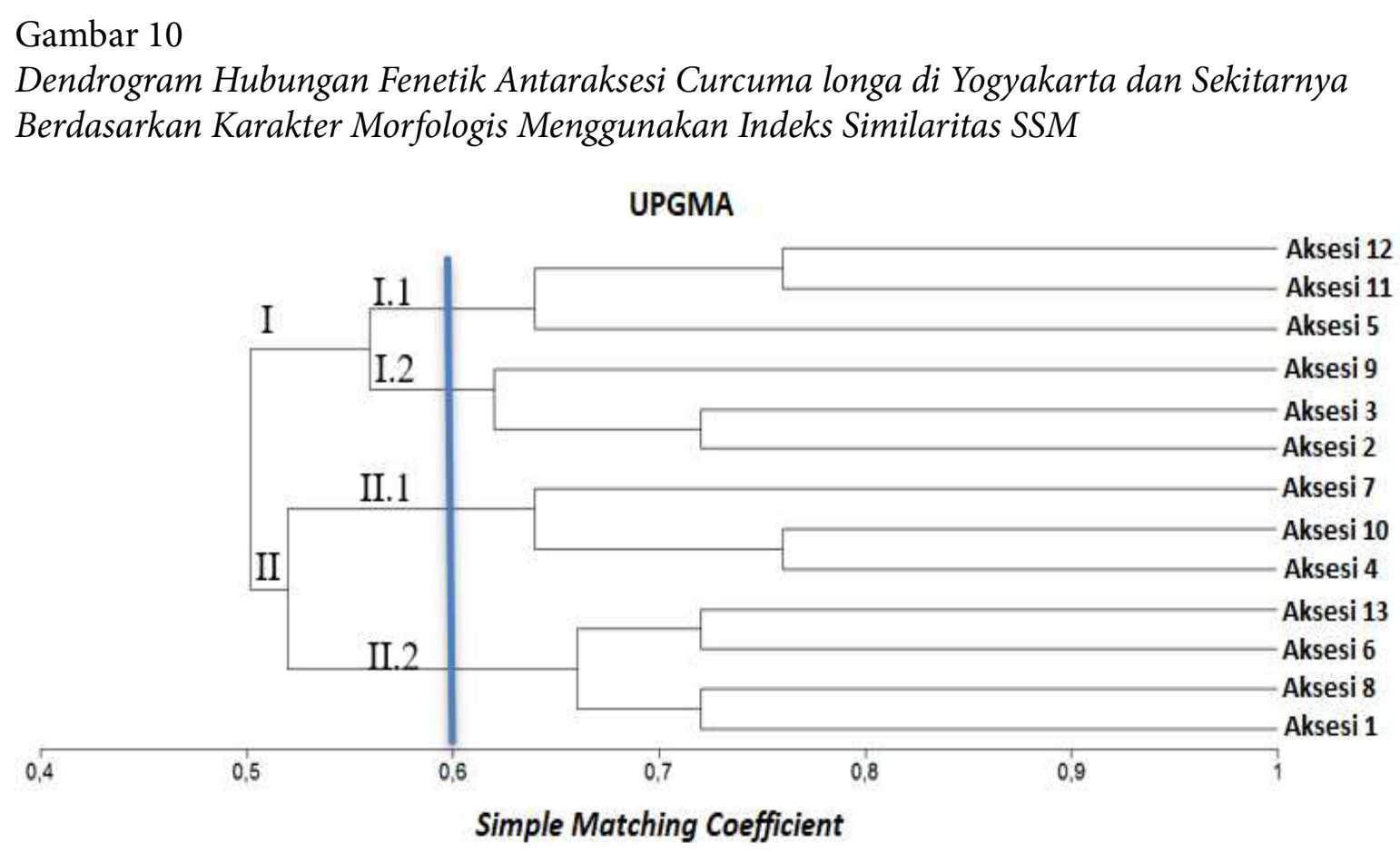

tersebut sama-sama memiliki tingkat similaritas tertingi dibandingkan pasangan aksesi lain. Berdasarkan PCA, karakter yang berpengaruh pada pasangan aksesi 11 dan 12 adalah MR3 atau bentuk rimpang samping dan MR7 atau jarak antarnodus rimpang utama (Gambar 11). Bentuk rimpang samping kedua aksesi tersebut adalah melengkung, sedangkan jarak antarnodus rimpag utama aksesi 11 adalah 0,6 cm dan aksesi 12 adalah 0,57 cm. Kedua pasangan aksesi ini memiliki 19 karakter biner yang sama. Karakter yang berpengaruh terhadap pasangan aksesi 4 dan 10 adalah MD5 yang merupakan singkatan dari karakter tangkai daun. Panjang rerata tangkai daun kedua aksesi tersebut relatif mirip yaitu 26,67 dan
25,33. Selain MD5, karakter MT1 atau tinggi habitus juga memiliki kemiripan ukuran yaitu $120,5 \mathrm{~cm}$ pada aksesi 4 dan $119 \mathrm{~cm}$ pada aksesi 10. Dari 25 karakter morfologis, aksesi 4 dan 10 memiliki 15 karakter biner yang sama.

Pengamatan karakter anatomis dilakukan pada organ daun dan rimpang. Organ daun dan rimpang dijadikan sebagai objek karakter anatomis karena dinilai memiliki karakter yang variatif dan lebih mudah dalam pembuatan preparat. Karakter anatomis yang diamati secara keseluruhan merupakan karakter kuantitatif diakrenakan tidak ditemukan perbedaan yang jelas. Karakter anatomis yang diamati adalah penampang melintang dan paradermal daun, 
Gambar 11

Scatter Plot dari Principal Component Analysis (PCA) Hubungan Fenetik Antaraksesi Curcuma longa di Yogyakarta dan Sekitarnya Berdasarkan Karakter Morfologis

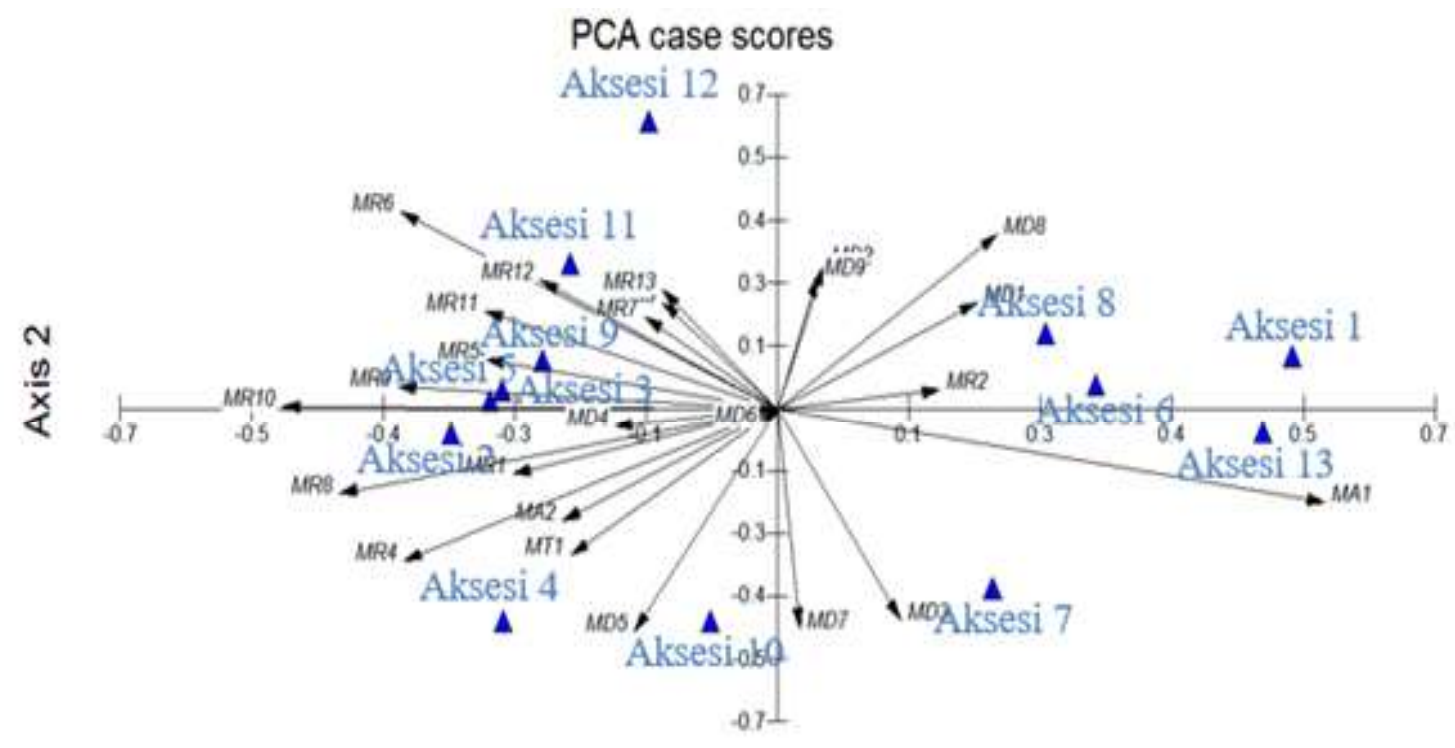

Axis 1

serta penampang melintang dari rimpang utama.

Karakter anatomis yang diamati meliputi ketebalan jaringan, densitas stomata, dan ukuran sel. Penampang melintang dilakukan pengamatan pada bagian midrib dan lamina daun, sedangkan penampang paradermal digunakan untuk pengamatan densitas stomata dan ukuran stomata. Pengamatan stomata dilakukan pada sisi abaksial daun menunjukkan distribusi stomata pada berbagai tanaman banyak terdapat pada sisi abaksial daun (Dlory dkk., 2013; Megia dkk., 2015; Papuangan dkk., 2014).

Pembuatan preparat melintang daun dilakukan secara semi permanen sehingga sampel yang telah dipotong menggunakan mikrotom harus segera disimpan dalam alkohol 70\% setelah diamati (Gambar 12). Ketebalan yang cukup pada bagian midrib daun membuat sampel dapat langsung dipotong menggunakan sliding microtome tanpa perlu melakukan proses embedding. Selain hal tersebut, pembuatan preparat tanpa embedding juga dinilai lebih praktis dan dapat mengurangi biaya.

Daun Curcuma longa tediri dari jaringan pelindung (epidermis dan derivatnya), jaringan dasar (mesofil), jaringan pengangkut, dann jaringan penguat (palisade). Jaringan pelindung $C$. longa tersusun atas epidermis adaksial dan epidermis abaksial. 


\section{Gambar 12}

Penampang Melintang Midrib ( $a \& b)$ dan Lamina (c\&d) Curuma longa Aksesi 1 (a \& c) serta Aksesi $9(b \& d)$
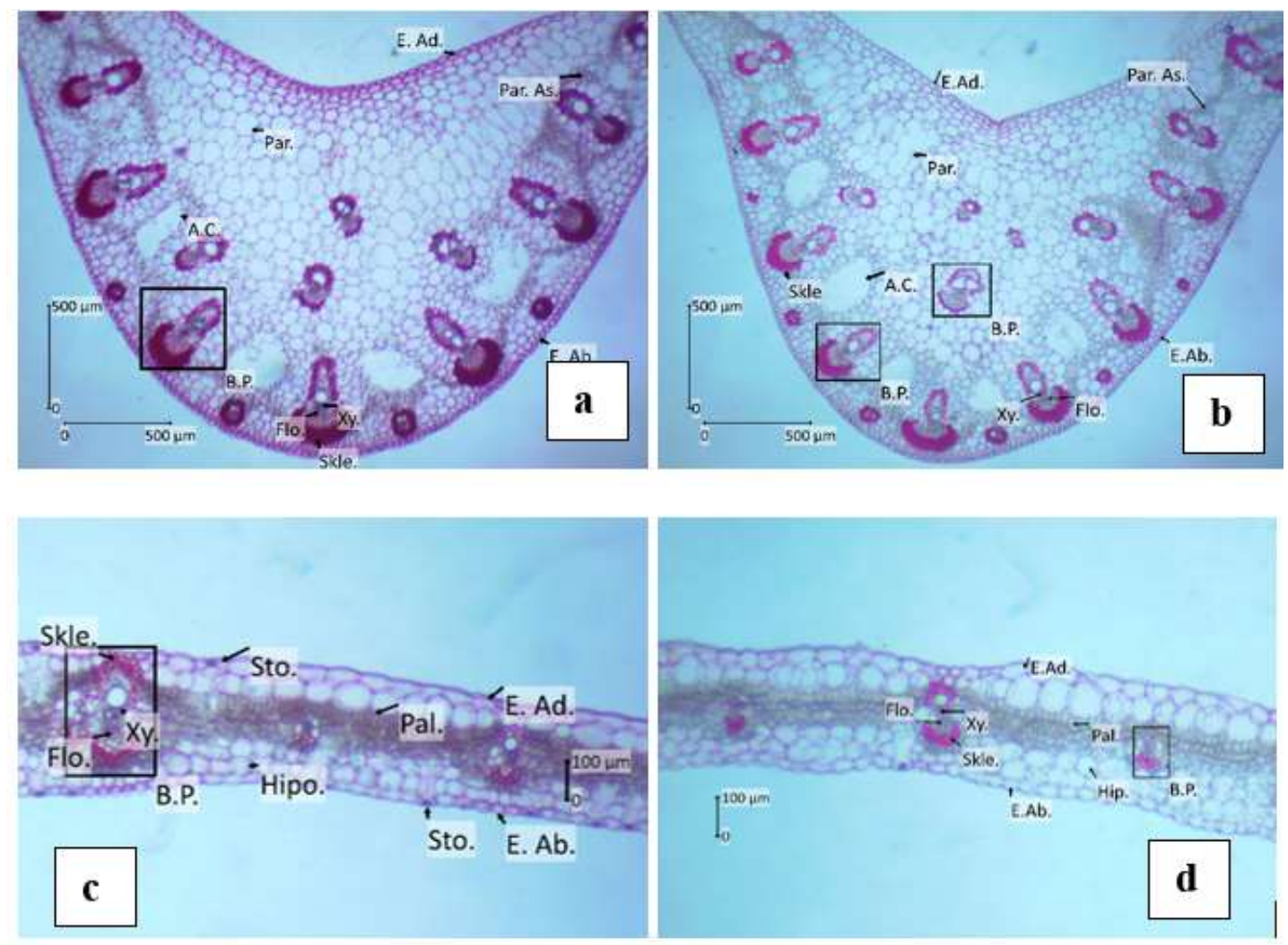

Keterangan: E.Ad.; epidermis adaksial, Par. As.; parenkim asimilasi, Par.; parenkim, A.C.; ruang udara, B.P.; berkas pengakut, E.Ab; epidermis abaksial, Xy.; xilem, Flo.; floem, Skle.; sklerenkim, Sto.; stomata, Pal.; palisade, Hipo.; hipodermis.

Ukuran epidermis pada bagian midrib hampir sama antara bagian adaksial dan abaksial. Semakin menuju ke arah lamina, ukuran jaringan epidermis mengalami perubahan lebih besar pada bagian adaksial. Derivat epidermis yang terlihat adalah stomata yang banyak terdapat dibagian abaksial. Stomata juga terlihat pada bagian adaksial walaupun dalam jumlah sedikit (Gambar 12c) sehingga disebut daun amfistomatik
(Ningsih dkk., 2011). Berdasarkan posisinya, stomata $C$. longa terletak sejajar dengan epidermis sehingga termasuk stomata paneropor (Nugroho dkk., 2012). Mesofil daun C. longa tersusun atas palisade yang berbentuk silindris, tegak pada permukaan daun, lebih dari satu lapis sel, dan tersusun rapat. Berkas pengangkut C.longa terletak dekat epidermis abaksial dan terdapat ruang udara diantara berkas pengangkut. Berkas- 
berkas pengangkut kecil juga terlihat seperti penghubung antara berkas pengangkut besar. Susunan xilem terletak di sebelah dalam floem dan tidak ditemukan adanya kambium, sehingga tipe berkas pengangkut C. longa adalah kolateral tertutup. Jaringan penguat pada C. longa merupakan jaringan sklerenkim yang dijumpai pada berkas pengangkut.

Pengukuran pada penampang melintang midrib dilakukan pada jaringan epidermis yaitu epidemis adaksial dan epidermis abaksial. Ketebalan epidermis dapat berbeda karena pengaruh faktor lingkungan. Ketebalan epidermis merupakan salah satu bentuk adaptasi tumbuhan dengan tujuan mengurangi laju transpirasi (Tihurua dkk., 2020). Ketebalan jaringan palisade dapat berbanding lurus terhadap kandungan kloroplast. Hal ini dikarenakan fungsinya untuk menangkap cahaya, kepadatan jaringan palisade dipengaruhi oleh intensitas cahaya. Berdasarkan pengukuran anatomis lamina C. longa, hasil yang diperoleh tidak sesuai teori. Aksesi 8 memiliki ketebalan tertinggi serta aksesi 6 memiliki ketebalan terendah. Intensitas cahaya pada aksesi 8 sebesar 136,6 x 100 lux dan pada aksesi 6 sebesar $561 \times 100$ lux. Hal ini dapat dikarenakan faktor yang berpengaruh tidak hanya intensitas cahaya, namun juga ketersediaan air dan hara. Jaringan palisade di antaranya tersusun atas kloroplas, yang dalam proses pembentukannya membutuhkan kecukupan unsur hara seperti $\mathrm{Cu}, \mathrm{Mn}$, dan $\mathrm{Fe}$ (Gunawan, 2011). Berdasarkan pengukuran kelembapan tanah aksesi 8 memiliki tingkat kelembapan $85 \%$, sedangkan aksesi 6 memiliki tingkat kelembapan $40 \%$. Hal ini menjadi faktor ketersediaannya molekul air pada tanah.

Pengamatan paradermal daun bertujuan mengetahui densitas dan ukuran stomata (Gambar 13). Ukuran dari stomata dipengaruhi oleh kondisi sel penjaga. Apabila sel penjaga terbuka maka lebar stomata dapat bertambah. Tanaman beradaptasi terhadap cekaman kekeringan salah satunya dengan mengurangi ukuran atau densitas stomata (Lestari, 2006). Lebar stomata terbesar dimiliki oleh aksesi 1 dengan lebar stomata mencapai $26,52 \mu$, sedangkan lebar stomata terkecil dimiliki oleh aksesi 10 dengan lebar stomata hanya $22,09 \mu$.

Densitas stomata pada aksesi C. longa memiliki rentang nilai $65-84$ per 10 kali perbesaran mikroskop. Densitas stomata paling sedikit ditemukan pada aksesi 7, sedangka densitas stomata terbanyak pada aksesi 11. Hal ini dapat dikarenakan panjang dan lebar stomata pada aksesi 7 lebih besar dari aksesi 11 sehingga kerapatan yang terlihat pada aksesi 7 lebih sedikit.

Kedua, penampang melintang rimpang. Karakter anatomis yang diamati pada rimpang C. longa berdasarkan ketebalan jaringan rimpang dan densitas sel minyak. 
Gambar 13

Preparat Paradermal Daun Curcuma longa Aksesi 1(a) dan Aksesi 10(b)
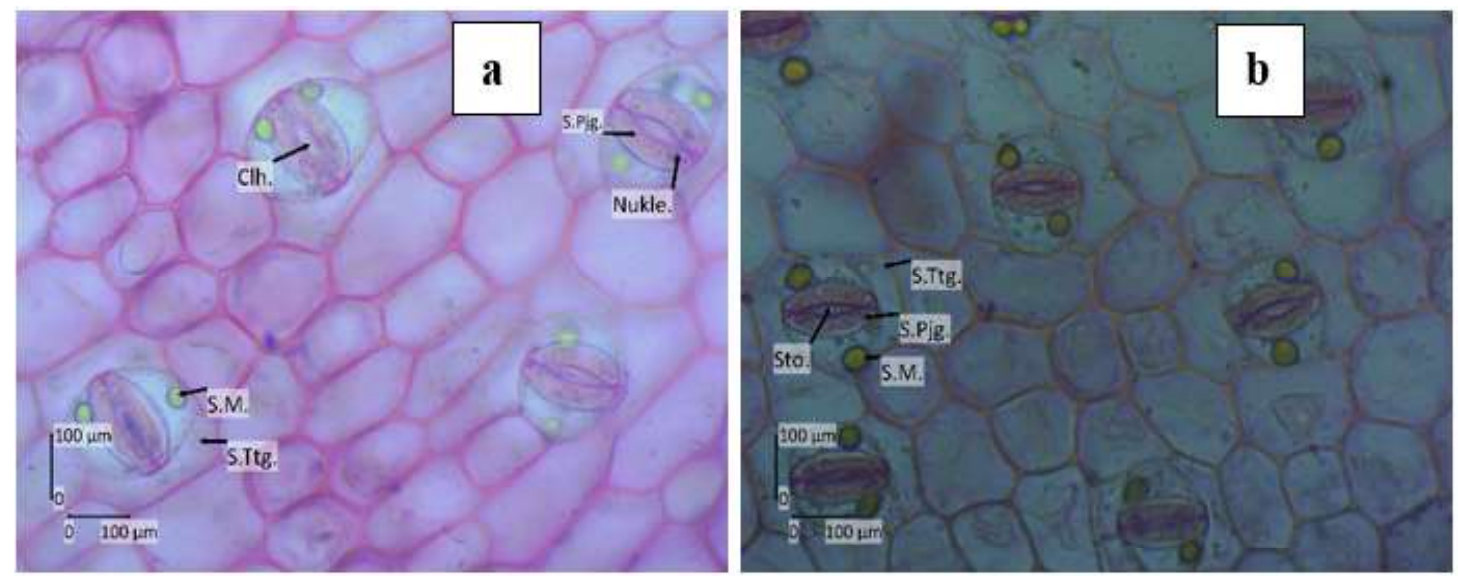

Keterangan: Clh; celah stomata, S.M; sel minyak, S.Ttg; sel tetangga, S.Pjg; sel penjaga, Sto; stommata, Nukle; nukleus.

Struktur rimpang $C$. longa tersusun atas epidermis, korteks, dan stele (Gambar 8). Bagian epidermis $C$. longa berwarna lebih gelap sehingga pengukuran epidermis digabung dengan hipodermis. Rimpang $C$. longa mengalami pertumbuhan sekunder sehingga membentuk kambium gabus (felogen) yang berkembang keluar menjadi gabus (felem) dan kedalam menjadi parenkim (feloderm). Korteks rimpang $C$. longa tersusun atas sel-sel parenkim, berkas pengangkut, dan sel minyak. Di antara jaringan korteks dan stele dipisahkan oleh endodermis. Berkas pengangkut pada $C$. longa memiliki struktur xilem yang terletak berdampingan dengan floem tanpa adanya kambium sehingga tipe berkas pengangkut ini termasuk kolateral tertutup. Pengukuran ketebalan berkas pengangkut diperoleh kisaran ketebalan yaitu $168 \mu$ hingga $392 \mu$.

Ketebalan epidermis dan hipodermis rimpang berada pada kisaran $196 \mu$ hingga $877 \mu$. Rimpang yang memiliki ketebalan epidermis dan hipodermis terkecil adalah rimpang aksesi 11, sedangkan ketebalan terbesar dimiliki oleh aksesi 3. Ketebalan jaringan gabus rimpang diukur dari felem hingga feloderm. Ketebalan jaringan gabus berada pada kisaran $129 \mu$ hingga $217 \mu$. Ketebalan korteks yang terukur pada kisaran $2,1 \mathrm{~mm}$ hingga $3,4 \mathrm{~mm}$. Jaringan gabus dengan ukuran terkecil dimiliki oleh aksesi 1, sedangkan ukuran terbesar dimiliki oleh aksesi 2. Ketebalan korteks yang terbesar dimiliki oleh aksesi 12 , sedangkan ketebala terkecil dimiliki oleh aksesi 1. Ketebalan 


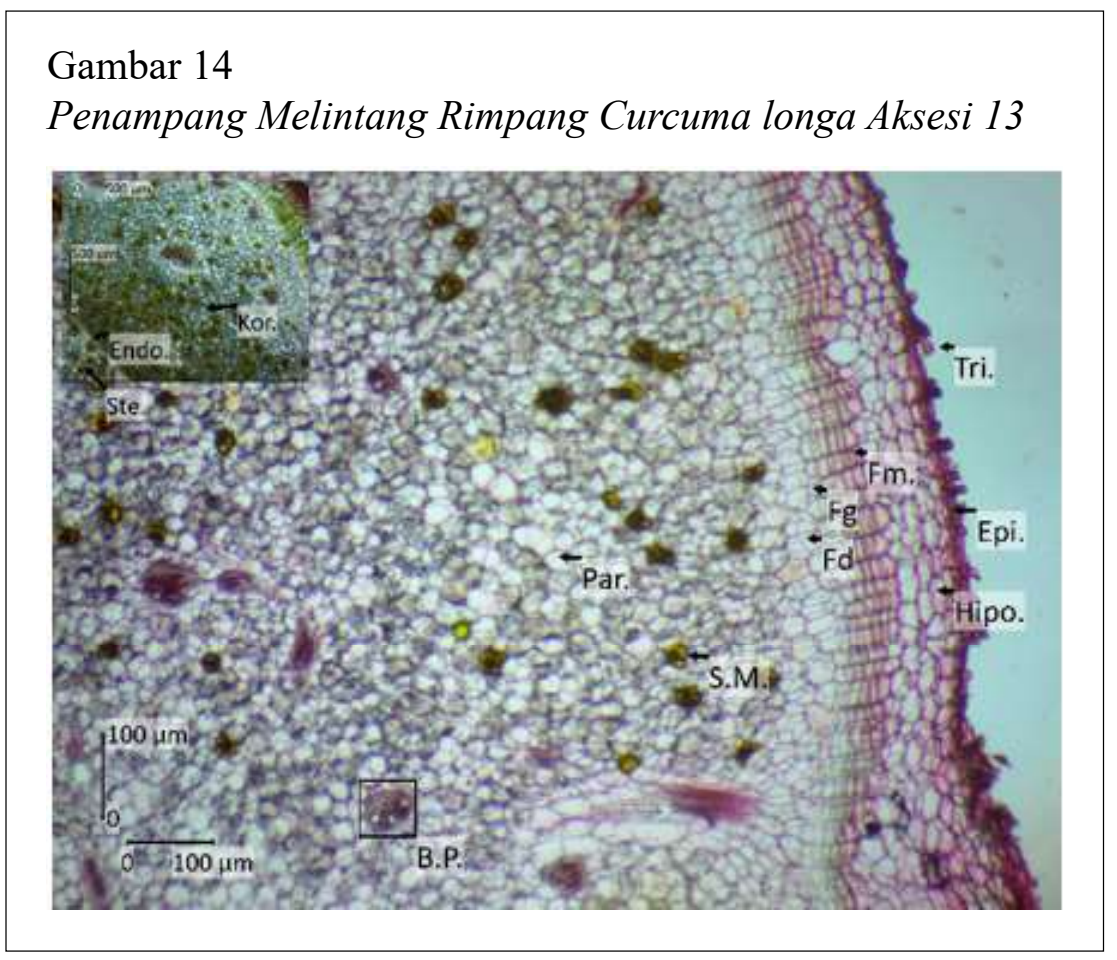

korteks dan stele dapat dipengaruhi oleh ketersediaan nutrien, dikarenakan rimpang menjadi tempat menyimpan cadangan makanan. Selain ketersediaan nutrien yang cukup, usia rimpang juga menjadi faktor yang berpengaruh terhadap ketebalan rimpang. Pengukuran diambil dari tiga bidang pandang kemudian diambil rata-rata ketebalan.

Pengukuran densitas sel minyak pada rimpang dilakukan dengan perbesaran $4 \mathrm{x}$ dan diperoleh jumlah densitas 89-213 sel per 4x perbesaran mikroskop. Dari rentang nilai tersebut kemudian dilakukan pengolahan data menjadi biner untuk dijadikan skor karakter. Sel minyak rimpang kunyit merupakan minyak atsiri yang memiliki kandungan metabolit sekunder. Banyaknya densitas sel minyak menjadi potensi banyaknya kandungan metabolit sekunder pada rimpang.

Ketiga, hubungan fenetik aksesi Curcuma longa berdasarkan karakter anatomis. Karakter anatomis yang telah diperoleh meupakan karakterkuantitatifyang kemudian digunakan untuk tabulasi data berbentuk biner, dan dilakukan pemberian skor. Terdapat 14 karakter anatomis yang telah diubah menjadi data biner dengan skor yang ditampilkan pada Tabel 7.

Seperti pada karakter morfologis, karakter anatomis juga digunakan untuk rekostruksi dendrogram menggunakan program Multi Variate Statistical Package (MVSP) dengan metode klastering dengan algoritma Unweighted Pair Group Method With Arithmetic Mean (UPGMA) dan 
Variasi dan Hubungan Fenetik (Guna, A. V. \& Purnomo)

Tabel 7

Presensi dan Absensi Setiap Karakter Anatomis yang Dibandingkan

\begin{tabular}{|c|c|c|c|c|c|c|c|c|c|c|c|c|c|c|}
\hline \multirow{2}{*}{ No } & \multirow{2}{*}{ Karakter } & \multicolumn{13}{|c|}{ OTU } \\
\hline & & 1 & 2 & 3 & 4 & 5 & 6 & 7 & 8 & 9 & 10 & 11 & 12 & 13 \\
\hline 1 & Lebar stomata daun & 1 & 0 & 1 & 1 & 0 & 0 & 1 & 1 & 1 & 0 & 1 & 1 & 1 \\
\hline 2 & Panjang stomata daun & 1 & 0 & 0 & 0 & 0 & 0 & 1 & 1 & 1 & 0 & 1 & 1 & 1 \\
\hline 3 & Densitas stomata daun & 0 & 1 & 1 & 0 & 0 & 0 & 0 & 0 & 1 & 1 & 1 & 1 & 0 \\
\hline 4 & Ketebalan epidermis adaksial mirdrib & 1 & 1 & 1 & 1 & 0 & 0 & 0 & 1 & 0 & 0 & 0 & 1 & 0 \\
\hline 5 & Ketebalan epidermis abaksial midrib & 1 & 0 & 0 & 1 & 1 & 0 & 1 & 1 & 0 & 0 & 0 & 1 & 1 \\
\hline 6 & Ketebalan epidermis adaksial lamina & 1 & 0 & 1 & 1 & 0 & 0 & 0 & 0 & 1 & 0 & 0 & 1 & 1 \\
\hline 7 & Ketebalan epidermis abaksial lamina & 1 & 1 & 1 & 1 & 0 & 0 & 0 & 0 & 1 & 1 & 1 & 1 & 0 \\
\hline 8 & Ketebalan ikatan pembuluh daun & 1 & 1 & 0 & 1 & 1 & 0 & 1 & 0 & 0 & 0 & 1 & 0 & 1 \\
\hline 9 & Ketebalan jaringan palisade & 0 & 0 & 1 & 1 & 0 & 1 & 1 & 1 & 1 & 1 & 1 & 1 & 1 \\
\hline 10 & $\begin{array}{l}\text { Ketebalan jaringan epidermis dan } \\
\text { hipodermis rimpang }\end{array}$ & 0 & 1 & 1 & 0 & 1 & 0 & 0 & 0 & 1 & 0 & 0 & 0 & 0 \\
\hline 11 & Lebar jaringan gabus rimpang & 0 & 1 & 1 & 0 & 1 & 0 & 0 & 0 & 0 & 1 & 0 & 1 & 0 \\
\hline 12 & Lebar jaringan korteks rimpang & 0 & 1 & 0 & 0 & 0 & 1 & 0 & 0 & 1 & 0 & 1 & 1 & 0 \\
\hline 13 & Ketebalan berkas pengangkut rimpang & 0 & 0 & 1 & 0 & 1 & 0 & 1 & 0 & 0 & 1 & 0 & 0 & 0 \\
\hline 14 & Jml sel minyak rimpang per $4 x$ perbesaran & 0 & 1 & 0 & 1 & 0 & 0 & 0 & 0 & 1 & 1 & 1 & 1 & 1 \\
\hline
\end{tabular}

pengukuran similaritas dengan indeks similaritas Simple-Matching Coeficient (SSM).

Hasil analisis klaster pada Gambar 10 menunjukan terdapat dua klaster yang terbagi menjadi empat subklaster dan dua subklaster. Klaster I.1 terdiri dari aksesi 6, klaster I.2 terdiri dari aksesi 5, klaster I.3 terdiri dari aksesi 10 dan 3, klaster I.4 terdiri dari aksesi 2. Klaster II.1 terdiri dari aksesi 12, 11, dan 9, sedangkan aksesi II.2 terdiri dari aksesi 8, 7, 13, 4, dan 1. Berdasarkan gambar 10, diketahui aksesi yang memiliki hubungan fenetik terdekat adalah aksesi 11 dan 9, 8 dan 7, serta 4 dan 1. Aksesi 11 dan 9 memiliki 12 karakter biner yang sama, sedangkan aksesi 8 dan 7 serta aksesi 4 dan 1 masing-masing memiliki 11 karakter biner yang sama. Tingkat similaritas ketiga pasangan tersebut memiliki nilai indeks similaritas diatas 75\%. Berdasarkan analisis PCA, karakter yang berpengaruh terhadap similaritas aksesi 9 dan 11 adalah AR5 atau densitas sel minyak rimpang per satuan luas perbesaran 4x mikroskop. Densitas terhitung pada aksesi 9 adalah 161 sel, sedangkan pada aksesi 11 memiliki densitas terhitung yaitu 155 sel. Densitas terhitung pada seluruh aksesi memiliki kisaran 89-213 sel minyak.

Penggunaan koefisien similaritas pada penelitian ini menggunakan SSM. Namun, percobaan juga dilakukan menggunakan koefisien similaritas Jaccard coefficient, euclidean coefficient, dan sorensen's 


\section{Gambar 15}

Scatter Plot dari Principal Component Analysis (PCA) Hubungan Fenetik Antaraksesi

Curcuma longa di Yogyakarta dan Sekitarnya Berdasarkan Karakter Anatomis

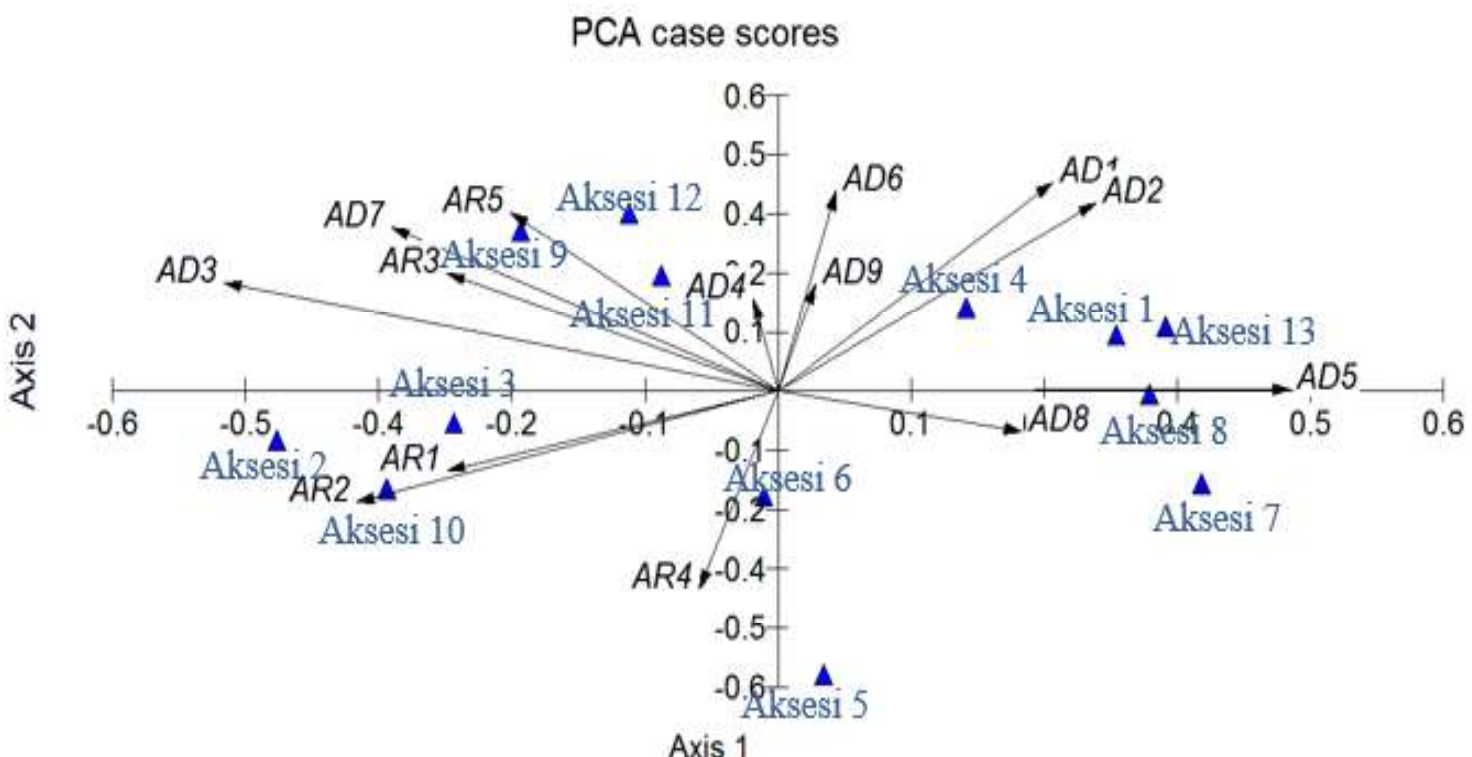

Axis 1

coefficient. Hasil dendrogram menunjukkan nilai similaritas yang sangat kecil. Sedangkan percobaan menggunaakan Gower General Similarity Coefficient menghasilkan bentuk dendrogram dan PCA yang sama. Hal ini dikarenakan prinsip dari Gowe General Similarity Coefficient adalah membagi jumlah atribut yang sama dengan jumlah variabel (Romesburg, 2004). Koefisien similaritas SSM juga memiliki prinsip yang sama (Verma \& Aggarwal, 2019).

\section{SIMPULAN}

Berdasarkan penelitian yang telah dilaksanakan diperoleh kesimpulan bahwa variasi morfologis Curcuma longa di Yogyakarta dan sekitarnya antara lain warna kulit dan bentuk rimpang samping, tinggi tanaman, ukuran daun, venasi helaian daun, panjang tangkai daun, serta kerimbunan akar dan rimpang samping. Variasi anatomis yang telah diamati antara lain ketebalan epidermis adaksial lamina, ketebalan berkas pengangkut di midrib, densitas sel minyak rimpang, serta ketebalan jaringan epidermis dan hipodermis rimpang. Berdasarkan analisis fenetik Curcuma longa di Yogyakarta dan sekitarnya dapat diketahui bahwa hubungan kekerabatan fenetik berdasarkan karakter morfologis terbagi menjadi dua klaster besar dan empat subklaster, sedangkan berdasarkan karakter anatomis terbagi menjadi dua klaster dan enam subklaster. 


\section{DAFTAR PUSTAKA}

Anni, I. A., Saptiningsih, E., \& Haryanti, S. (2013). Pengaruh naungan terhadap pertumbuhan dan produksi tanaman bawang daun (Allium fistulosum L.) di Bandungan, Jawa Tengah. Jurnal Biologi, 2(3), 31-40.

Campbell, N. A., Reece, J. B., Urry, L. A., Cain, M. L., Wasserman, S. A., Minorsky, P. V., \& Jackson, R. B. (2012). Biologi: Edisi 8 Jilid 2. (D. T. Wulandari, Terj.) Jakarta: Erlangga.

Dharmayanti, I. N. (2011). Makalah filogenetika molekuler: Metode taksonomi organisme berdasarkan sejarah evolusi. Balai Besar Penelitian Veteriner.

Dlory, Ningrum, R. K., Suryantari, N. K., \& Anindita, F. L. R. (2013). Studi anatomi daun dari tiga anggota suku Malvaceae di Kawasan Waduk Jatiluhur. Proceeding Biology Education Conference, 13(1), 611-618.

Fajar, M. T. I., Purnomo, \& Handayani, N. S. N. (2016). Hubungan kekerabatan fenetik Lycopersicon esculentum Mill. Kultivar Betavila F1, Fortuna F1, dan Tymoti F1 berdasarkan tingkat kesamaan fenotip. Biota, 1(2), 91-97.

Gunawan, S. H. (2011). Untung besar: Dari usaha pembibitan kayu. AgroMedia.

Iskandar, J. (2016). Etnobiologi dan keragaman budaya di Indonesia. Indonesian Journal of Anthropology, 1(1), 27-42.

Lestari, E. G. (2006). Hubungan antara kerapatan stomata dengan ketahanan kekeringan pada somaklon padi Gajahmungkur, Towuti, dan IR 64. Biodiversitas, 7(1), 44-48.

Lynch, J. P., \& Brown, K. M. (2012). New roots for agriculture: Exploiting the root phenome. Philosophical of Transaction of the Royal Society B: Biological Science, 367, 1598-1604.

Megia, R., Ratnasari, \& Hadisunarso. (2015). Karakteristik morfologi dan anatomi, serta kandungan klorofil lima kultivar tanaman penyerap polusi udara Sansevieria trifasciata. Jurnal Sumberdaya Hayati, 1(2), 34-40.

Naik, V.N.(2006). Taxonomyofangiosperms. Tata McGraw-Hill Publishing Company Limited.

Naik, V. N. (2012). Identification of common Indian medicinal plants. Scientific Publishers.

Ningsih, R., Darwanti, I., Meiga, R., \& Roostika, I. (2011). Karakter anatomi daun kultur purwoceng pascakonservasi in vitro. Buletin Plasma Nutfah, 17(1), 30-39.

Nugroho, L. H., Purnomo, \& Sumardi, I. (2012). Struktur \& perkembangan tumbuhan. Penebar Swadaya.

Papuangan, N., Nurhasanah, \& Djurumudi, M. (2014). Jumlah dan distriusi stomata pada tanaman penghujan di Kota Ternate. Jurnal Bioedukasi, 3(1), $287-$ 292.

Protection of Plant Varieties and Farmers' Right Authority [PPV \& FRA]. (2007). Guidelines for the conduct of test for distinctiveness, uniformity and stability on Turmeric (Curcuma longa L.). Goverment of India. Diunduh dari https://www.google.com/.

Pujiasmanto, B. (2020). Peran dan manfaat hormon tumbuhan: Contoh kasus paclobutrazol untuk penyimpanan benih. Yayasan Kita Menulis.

Ravindran, P. N., Babu, K. N., \& Sivaraman, K. (2007). Turmeric: The genus curcuma. CRC Press.

Romesburg, H. C. (2004). Cluster analysis for researchers. Diunduh dari Lulu.com.

Roy, B., Jana, B. K., \& Maiti, G. G. (2013). Morpho-anatomical diversity of the rhizomes of some medicinal and aromatic plants of zingiberaceae. International Journal of Chemical and Pharmaceutical Research, 2(8), 197203.

Salimpour, F., Ebrahimiyan, M., Sharifnia, F., \& Tajadod, G. (2012). Numerical taxonomy of eight Salvia L. species using anatomical properties. Annals of Biological Research, 3(2), 795-805. 
Silalahi, M. (2017). Pemanfaatan Curcuma longa (L.) oleh masyarakat lokal di Indonesia dan kandungan metabolit sekundernya. Pro-Life, 4(3), 430-440.

Singh, G. (2004). Plant systematics: An intergrated approach. Science Publishers.

Tihurua, E. F., Agustiani, E. L., \& Rahmawati, K. (2020). Karakter anatomi daun sebagai bentuk adaptasi tumbuhan penyusun zonasi mangrovedi banggai Kepulauan, Provinsi Sulawesi Tengah. Jurnal Kelautan Tropis, 23(2), 255-264.
Trimanto, Dwiyanti, D., \& Indriyani, S. (2017). Morfologi, anatomi, dan uji histokima rimpang Curcuma aeruginosa Roxb; Curcuma longa L.; dan Curcuma heyneana Valeton dan Zijp. Jurnal Berita Biologi LIPI, 17(2), 123-133.

Verma, V., \& Aggarwal, R. K. (2019). A new similarity measure based on simple matching coefficient for improving the accuracy of collaborative recommendations. International Journal Information Technology and Computer Science, 6(1), 37-49. 